\title{
Acquisition of Electric Vehicles-A Step towards Green Consumption. Empirical Research among Romanian Students
}

\author{
Gabriel Brătucu ${ }^{1}$, Adrian Trifan ${ }^{1}$, Lavinia Dovleac ${ }^{1, *}$, Ioana Bianca Chițu ${ }^{1}$, \\ Raluca Dania Todor ${ }^{1}$ and Rareș Brătucu ${ }^{2}$ \\ 1 Faculty of Economic Sciences and Business Administration, Transilvania University of Braşov, \\ Colina Universitatii street, no. 1, Building A, Braşov 500068, Romania; gabriel.bratucu@unitbv.ro (G.B.); \\ adrian.trifan@unitbv.ro (A.T.); ioana.chitu@unitbv.ro (I.B.C.); raluca.todor@unitbv.ro (R.D.T.) \\ 2 Faculty of Marketing, Academy of Economic Studies, Piața Romană street, no. 6, Bucharest 010374, Romania; \\ raresbratucu@yahoo.com \\ * Correspondence: lavinia.dovleac@unitbv.ro
}

Received: 25 October 2019; Accepted: 22 November 2019; Published: 24 November 2019

\begin{abstract}
The paper analyzes particular aspects of a competitive economy based on low carbon emissions, which requires a fundamental change in consumer behavior, by focusing mainly on green acquisitions. The article contributes to the literature by the novelty of the researched problem: identification and analysis of the attitude and behavior of Romanian students regarding the electric vehicles acquisition. Thus, a quantitative marketing research was conducted, using a sample of 1221 students from 11 Romanian university centers. Also, the paper includes an overview regarding the costs and financial benefits provided by the Romanian Government to the electric vehicles owners, such as acquisition price reductions or tax reductions. The research results show that only half of the students are familiar with the concept of green consumption, and $37.8 \%$ of them are interested in buying an electric vehicle, the main reason being the fuel consumption. The authors recommend to the state's institutions to develop special programs, by offering attractive facilities to the young people with higher education, as potential buyers, for the purchase of electric vehicles, this way diminishing the barrier effect generated by the high price. The academic environment should initiate research, both at the micro and macroeconomic level, to quantify the economic-social implications of green acquisitions in general and electric vehicles in particular.
\end{abstract}

Keywords: green acquisition; electric vehicles; green consumption; quantitative marketing research; costs; advantages

\section{Introduction}

In the context of the climate change we are currently facing, an important objective of the European Union (EU) is to reduce greenhouse gas emissions by at least $40 \%$ by 2030 , compared to 1990 [1]. Regarding transportation, the EU target for 2050 is to reduce $\mathrm{CO}_{2}$ emissions by $60 \%$ (compared to 1990), given that transport is responsible for $30 \%$ of total $\mathrm{CO}_{2}$ emissions, and $72 \%$ of this comes from road transport [2].

Achieving a competitive economy based on low carbon emissions requires a fundamental change in consumer behavior, mainly focusing on green acquisition. In the opinion of many specialists, this behavioral change can be achieved through the transition to electric vehicles [3]. This is a necessity both because of the very high $\mathrm{CO}_{2}$ emissions and air pollution, but also the high consumption of fossil fuels [4]. Currently, most cars in Europe use gasoline (52\%) and diesel (37\%), but the number of electric vehicles has steadily increased, for example, by 51\% in 2017 compared to 2016 [2]. At the 
same time, consumers in emerging markets tend to have sustainable behavior, being concerned about environmental conservation [5].

Starting from the data according to which the share of new green cars in total sales, in Romania, was $3.40 \%$, between January and May 2019, compared to 2.30\% in the same period from 2018, the authors wanted to obtain information related to the attitude and behavior of the Romanian students towards the acquisition of electric vehicles. They started from the premise that young people with higher education are much more likely to change their consumption behavior, due to their friendlier attitude towards the environment. Considering these aspects, a quantitative marketing research was conducted among the students from 11 university centers. In this context, the paper aims to address issues related to the changes in the behavior of young consumers with higher education regarding potential green acquisitions, mainly electric vehicles. Thus, the main research objective was the identification and analysis of the attitude and behavior of the Romanian students towards the acquisition of an electric vehicle. Given the proposed objective, the main research questions are: (1) To what extent are Romanian students familiar with the concept of green behavior? (2) Are Romanian students willing to purchase an electric vehicle? Also, the paper includes an overview regarding the costs and financial benefits provided by the Romanian Government to the electric vehicles owners, such as acquisition price reductions or tax reductions.

The research results revealed that half of the Romanian students are generally familiar with the concept of green consumption, and $37.8 \%$ of them are interested in buying an electric vehicle. The most common reason why students want to make such a purchase is related to the fuel consumption. To achieve the aim, the authors have structured the paper into 4 sections. Thus, after reviewing the scientific papers published on the topic of consumer behavior changes regarding green acquisition, the research methodology was described. Next, the results of the empirical investigation, as well as the related discussions, are presented, the paper being finalized with the research conclusions and proposals.

\section{Review of the Scientific Literature}

The development of smart green technologies, which low carbon emissions, is particularly important to meet future challenges, towards a sustainable society [6,7]. Electric cars are sustainable options for internal combustion engines, being energy efficient and contributing to $\mathrm{CO}_{2}$ reduction [8-10]. Reducing $\mathrm{CO}_{2}$ emissions is a global issue that can be partially solved by replacing fossil fuel powered vehicles with electrically driven ones. In this context, there is a need to develop sustainable development policies to facilitate public awareness of new changes in the automotive industry [11].

There are European countries that develop laws that encourage the rapid replacement of the car fleet with electric vehicles. France, UK is aiming to ban the sale of gas or diesel cars by 2040 at the latest [12]. In the Netherlands and Norway, there are discussions about approving a law prohibiting the sale of new fossil fuel engines after $2025[13,14]$. 15 years ago Norway decided to change its car fleet- and the measures taken were subsidies and tax exemptions so that the electric vehicles became much accessible, and now, the share of electric vehicles in the total of purchased vehicles has increased a lot in the last period, from 5\% in 2013 to over 30\% in 2018 and to 60\% in March 2019. At the same time, the owners of electric vehicles are exempt from the purchase tax and have other facilities (free parking, free tunnel entry a.s.o.) [15]. As well, this is an ongoing change process, as Norway plans to go even further with their strategy to reduce $\mathrm{CO}_{2}$ emissions in the transport sector. According to the National Transport Plan of Norway for the 2018-2029 period [16], in order to reduce these emissions, the Government established optimistic targets not just for conventional cars, but also for public transportation vehicles and other heavy duty vehicles. For example, by 2025, the following categories of road vehicles shall be zero emitters or use bio types of fuel: all new regular cars, all new light vans and all new urban buses. By 2030, all heavy duty vehicles, $75 \%$ of new long distance coaches and $50 \%$ of new trucks shall also be zero-emission vehicles. Of course, the effort that will be dedicated to creating the perfect infrastructure for these vehicles will be enormous. For the moment, the infrastructure 
for charging is quite significant. There are more than 11,000 publicly accessible charging stations in Norway, with more planned to be built. Electric vehicles' owners can use a dedicated app called Nobil, created by the Norwegian Electric vehicles Association, to always find empty spots in order to charge their vehicles [17]. However, as it was said, the infrastructure will be constantly developed in order to offer the best facilities for current and future owners of zero emitter vehicles, in order to sustain their progress towards the 2025 and 2030 goals. Norway's measures taken to influence citizens to purchase zero emissions vehicles are unbeatable, as taxes not only for owning a regular vehicle that runs on fossil fuel, but also for driving it anywhere in the country. Norway started implementing incentives for electric vehicles back in the 1990's and continues to do so today in a much more aggressive manner compared to regular vehicles. For example, the most significant electric vehicle incentives given by the Government are the following: no purchase and import taxes; no 25\% VAT on purchase; no annual road tax; maximum $50 \%$ of the total amount on toll roads (such as tunnels, bridges, highways) and on ferry fares; maximum $50 \%$ of the total amount or even free municipal parking; access to bus lanes etc. [18]. The example list goes on and it proves the point that Norway has done a great job in encouraging its citizens to fight for a zero emission future.

India wants all vehicles sold since 2030 to be electric, and China is aiming to become the fastest-growing state of electric vehicles, with the number of charging stations increasing to over 500,000 [19].

The interest in electric vehicles has increased in the context of climate change and energy independence concerns, with governments encouraging their acquisition [20]. Starting, for example, from public green acquisition, considered an important tool in promoting sustainable consumption [21,22] but also for stimulating the market [23,24], it is considered that green acquisition must become a normal consumption behavior and must be adapted to existing purchasing practices [25]. As domestic policy instruments, a study conducted in Portugal concludes that the increase of taxes and duties for the purchase of fossil fuel but also of traditional vehicles are the most efficient for increasing the acquisition of electric cars, but even so an increase of only $10 \%$ is expected by 2030 [26].

In Romania, according to the centralized data from the Association of Cars Manufacturers and Importers (APIA), between January and May 2019, 379 full electric cars were purchased $(+149.30 \%$ compared to the first five months of the previous year). In the top of the most commercialized full electric cars, in January-May 2019, the first place was occupied by Nissan, with 119 units, followed by Renault with 81 units, Volkswagen-68, Smart-59, BMW—40, Jaguar-9, Audi-2 and Mercedes Benz-1. The number of new green cars sold in Romania, in the first five months of 2019, was 2285 units, $69 \%$ more compared to the same period in 2018, shows APIA statistics. This statistics also include hybrid cars-1814 units, $71 \%$ more compared to the same period last year and plug-in 92 units, down $34.30 \%$ from the same period last year [27].

Although electric vehicles have positive consequences in reducing pollution, their number is still insignificant, a fact caused by the barriers that appear in their adoption by consumers [28]. In the literature there are numerous studies that highlight both the barriers that appear in the purchase of these vehicles and the factors that determine their acceptance or non-acceptance. Barriers are, on the one hand, related to the potential consumers. Their needs, the attitude towards these vehicles and to the environment, and on the other hand, to the necessary infrastructure [29]. The most important barrier identified by specialists in the purchase of electric cars is the gap between consumers' expectations and their perceptions regarding these products, a gap due to the information provided to consumers mainly related to the use period [30]. Biresselioglu, Kaplan and Yilmaz (2018) consider that the main barriers in purchasing electric cars are concerns about lack of charging infrastructure, costs, lack of trust, lack of information and concerns about their use [3]. Although the electric vehicles are considered energy efficient, they can produce gases and other sources of pollution due to the Li-ion battery. NBC Defense and Tsinghua University of China point out that these batteries can produce toxic gases when overloaded [31]. At the same time, the batteries have to be charged to a power source, which 
is often not a renewable one (green). Although renewable energy is beneficial not only to the users, but also to the environment, it is only at the early stage of development.

Through training and information, psychological barriers in the purchase of electric vehicles can be overcome $[30,32]$. So, specialists propose the use of positive emotions in promoting electric vehicles because the study's results show that the anticipated emotions of the purchase directly influence the consumer in the purchasing process [33].

There are several types of factors that underlie the low acceptance of electric cars by the population, respectively demographic, situational and psychological factors [34]. The costs of such an acquisition and the short usage time until recharging are considered to be the main factors hindering widespread acceptance, but on the other hand those who have tested electric cars consider that environmental performance is more important than the purchase price [35]. The factors influencing the adoption of electric vehicles are considered to be: Consumer preferences, costs, social status, habits, long-term benefits. In the EU, the most important factors are considered to be the costs and the assurance of mobility but also the profitability of the alternative options: Hybrid vehicles [8].

The study of electric vehicles consumer has shown interest in the academic environment for the last years. The results of a study conducted in the United Kingdom show that there are several types of consumers of electric vehicles differentiated by the socio-economic characteristics, the car features and the psychographic profiles, demonstrating that it is a stratified market that needs an approach on consumer segments, rather than a global one [36,37]. In China, the openness to innovation and the concern for the environment determines the purchase intention of electric vehicles $[9,38]$ but also the ease of use [39]. The purchase intention was investigated also from the point of view of functional values (performance, cost, convenience) and non-functional (emotional, social, epistemic) and the conclusion was that the functional values come first, an aspect that could be used in marketing strategies [40].

The acquisition of electric cars is influenced by the personal values that determine the concern for the environment and the moral obligations [41]. The main motivations are concerns regarding environmental conservation, economic and technical concerns but also personal and demographic factors [3]. At the same time, the purchase intention is also influenced by the consumers' background regarding the adoption of these car models, antecedents related to national cultural differences [42]. In Sweden, the main consumers of electric vehicles are men, with higher education, with medium to high incomes. These cars are used for private purposes and are charged at home during the night [10]. The intention to purchase an electric or hybrid vehicle is indirectly, but positively, affected by environmental conservation concerns $[39,43]$. On one side, there are consumers who have bought electric vehicles based on ecological motivations, which in the future will lead to sustainable energy behavior. On the other side, consumers have bought them for financial or technological reasons, having no link to the ecological aspects [44].

\section{Research Methodology}

Starting from the research problem (the identification of the aspects related to the change of the behavior of the young consumers with higher education regarding the potential green acquisitions, particularly electric vehicle) and based on the analysis of the literature, the following general assumptions were formulated: (1) Romanian students are interested in procuring electric vehicles but do not have the needed purchasing power. (2) A large part of the Romanian students intends to procure an electric vehicle, if they would receive consistent financial support from the State. (3) The still high price represents the main barrier in the acquisition of an electric vehicle by the Romanian students.

In order to reach the research objectives, a quantitative marketing research was carried out, based on the survey among students from 11 academic centers from Romania. According to the Romanian educational system, the academic centers are organized in 4 categories, based on their size: Very large -1 center (Bucharest), large (3 centers), medium (8 centers), small (37 centers). From each 
category, the authors selected the most representative local universities (13) based on their prestige and importance, according to the Romanian classification criteria.

The final sample consists of 1221 subjects being validated on the basis of the $t$-student test and rectified in order to ensure a balanced structure based on gender and age categories. The table below (Table 1) presents the sample structure organized by academic centers, universities and the number of respondents considered for the research.

Table 1. Sample structure by universities.

\begin{tabular}{|c|c|c|c|c|c|}
\hline No. & $\begin{array}{c}\text { Academic } \\
\text { Centre Name }\end{array}$ & $\begin{array}{l}\text { Academic } \\
\text { Centre Type }\end{array}$ & University & $\begin{array}{c}\text { No. of } \\
\text { Respondents }\end{array}$ & Percent \\
\hline \multirow{3}{*}{1} & \multirow{3}{*}{ Bucharest } & \multirow{3}{*}{ Very large } & $\begin{array}{l}\text { Academy of Economic } \\
\text { Studies, Bucharest }\end{array}$ & 132 & $10.8 \%$ \\
\hline & & & $\begin{array}{l}\text { Politehnica University } \\
\text { from Bucharest }\end{array}$ & 154 & $12.3 \%$ \\
\hline & & & $\begin{array}{l}\text { "Carol Davila" University } \\
\text { of Medicine and Pharmacy }\end{array}$ & 55 & $4.5 \%$ \\
\hline 2 & Cluj-Napoca & Large & Babeș Bolyai University & 165 & $13.5 \%$ \\
\hline 3 & Brasov & \multirow{4}{*}{ Medium } & $\begin{array}{l}\text { Transilvania University } \\
\text { from Brașov }\end{array}$ & 143 & $11.7 \%$ \\
\hline 4 & Sibiu & & $\begin{array}{l}\text { "Lucian Blaga" University } \\
\text { from Sibiu }\end{array}$ & 77 & $6.3 \%$ \\
\hline 5 & Galați & & $\begin{array}{l}\text { "Dunărea de jos" } \\
\text { University from Galați }\end{array}$ & 79 & $6.5 \%$ \\
\hline 6 & Craiova & & University of Craiova & 75 & $6.1 \%$ \\
\hline 7 & Arad & \multirow{5}{*}{ Small } & $\begin{array}{l}\text { "Aurel Vlaicu" University } \\
\text { from Arad }\end{array}$ & 64 & $5.2 \%$ \\
\hline 8 & Bacău & & $\begin{array}{l}\text { "Vasile Alecsandri" } \\
\text { University from Bacău }\end{array}$ & 68 & $5.6 \%$ \\
\hline 9 & Oradea & & University of Oradea & 68 & $5.6 \%$ \\
\hline 10 & Pitești & & University of Pitești & 75 & $6.1 \%$ \\
\hline \multirow[t]{2}{*}{11} & Suceava & & $\begin{array}{l}\text { "Ștefan cel Mare" } \\
\text { University from Suceava }\end{array}$ & 66 & $5.4 \%$ \\
\hline & \multicolumn{3}{|c|}{ Total } & 1221 & $100 \%$ \\
\hline
\end{tabular}

The sample structure by gender comprises $52.3 \%$ females and $47.7 \%$ males. Considering the age, in the $18-21$ age category falls $83.8 \%$ of respondents, in the $22-25$ years category $14.4 \%$ and $1.8 \%$ are over 26 years old.

For achieving the research objective, the authors considered as total research population all the students from the selected universities, aiming at determining both their opinions regarding the green consumption behavior in general, and their attitude about buying electric vehicles in particular.

The information was collected through an electronic questionnaire, using the computer assisted web interviewing (CAWI) method [45]. The authors used this method because of its advantages in collecting data using the Internet, by uploading the online questionnaire and filling it in directly in the browser by the respondent. This method requires no need to install an application/program. In the specialists' opinion, the method has as main advantage the reduced costs of data collection, compared to other specific methods [46]. The CAWI method has the disadvantage of the non-random selection of the respondents, which causes a reduced representativeness of the sample. However, in order to partially compensate this disadvantage, the authors collected data from a large number of subjects, but the results must be interpreted with some caution. 
The link to the questionnaire was sent by email or social networking sites. The collected data were processed using the SPSS program, applying univariate and bivariate analysis methods. Also, statistical tests were applied to establish the links between the research variables. The first aspect analyzed was determining the degree to which students know the concept of green behavior and electric vehicle. After that, aspects related to the students' attitude regarding the ownership of an electric vehicle, the interest to drive it, the willingness to purchase it, from their own sources or with state aid, were analyzed. For a more in-depth analysis of these aspects, the following hypotheses were tested using the $\chi^{2}$ test (chi square).

Hypothesis 1 (H1). The age influences the level of knowledge about green consumption.

Hypothesis 2 (H2). Gender influences the factors determining the decision to procure an electric vehicle.

Hypothesis 3 (H3). Gender influences the type of barriers that appear in the decision process to procure an electric vehicle.

\section{Results and Discussion}

The results are grouped on the main objectives of the research, and the analysis and statistical tests performed are presented in a logical sequence, which allowed obtaining relevant results.

\subsection{Determining the Degree to Which Students Are Familiar with the Concept of Green Consumption}

Given the current challenges related to the protection and conservation of the environment in order to create a sustainable model of production and consumption for the society, the degree to which students are aware of issues related to green consumption was measured. According to the results in the table below, about half of the students $(49.5 \%)$ are not familiar at all with this concept.

The low level of knowledge about this concept can be considered worrying because by making the right choices about acquisitions, consumers can play a major role in reducing the negative impact on the environment. In generating a green behavior, it is very important for individuals to be aware of the effect of their actions on the environment, because they can make the right decisions regarding the purchase and use of different products.

Based on the results from Table 2, the authors aimed to determine if the age influences respondents' level of knowledge about green consumption, this being the first statistical hypothesis of the research. For this purpose, the $\chi^{2}$ (chi-square) test was applied and the results are presented in the table below.

Table 2. The level of students' knowledge about the concept of green consumption.

\begin{tabular}{ccc}
\hline Level of Knowledge & No. of Respondents & Percent \\
\hline None & 605 & $49.5 \%$ \\
Somehow & 385 & $31.5 \%$ \\
High & 231 & $18.9 \%$ \\
\hline Total & $\mathbf{1 2 2 1}$ & $\mathbf{1 0 0} \%$ \\
\hline
\end{tabular}

For a 95\% confidence level, the significance level of the test from Table 3 has the value 0 , being less than 0.05 . This result leads to the conclusion that the age influences students level of knowledge about green consumption.

Table 3. Chi-square test values.

\begin{tabular}{lccc}
\hline & Value & df & Significance Level \\
\hline Pearson Chi-Square & 51.894 & 4 & 0.000 \\
No. of valid cases & 1221 & & \\
\hline
\end{tabular}


According to the results from Table 4, the very interesting aspect is that the percentage of respondents familiar with the concept of green consumption within the age group 18-21 years (19.4\%) is higher than the percentage of those in the category $22-25$ years $(18.8 \%)$.

Table 4. The level of students' knowledge regarding the concept of green consumption by age groups.

\begin{tabular}{ccccc}
\hline \multirow{2}{*}{ Age } & \multicolumn{3}{c}{ Level of Knowledge } & \multirow{2}{*}{ Total } \\
\cline { 2 - 4 } & None & Somehow & High & \\
\hline $18-21$ & $49.5 \%$ & $32.2 \%$ & $19.4 \%$ & $100 \%$ \\
$22-25$ & $56.3 \%$ & $25 \%$ & $18.8 \%$ & $100 \%$ \\
26 and over & $0 \%$ & $100 \%$ & $0 \%$ & $100 \%$ \\
Total & $49.5 \%$ & $31.5 \%$ & $18.9 \%$ & $100 \%$ \\
\hline
\end{tabular}

According to the research results, $62.2 \%$ of the students know what an electric vehicle is, and $10.8 \%$ of them came in contact with such a vehicle, as drivers or passengers.

\subsection{Identifying Students' Intentions to Buy Electric Vehicles}

The percentage of students willing to buy an electric vehicle is $37.8 \%$ (462 respondents). The percentage is encouraging, given that electric mobility is a solid and credible, long-term alternative to the internal combustion engine. This percentage is close to that of British youths ( $40 \%)$ identified in a study from 2018, which shows that the views of young Romanians are similar to those of young people from economically advanced European countries [47].

According to Figure 1, the most common reason why students want to buy an electric vehicle is related to the fuel consumption (41.6\%). A fairly high percentage (21.4\%) would buy such a vehicle due to their concern for the protection and conservation of the environment. The technology incorporated into an electric vehicle is another reason why a large proportion of students $(18.6 \%)$ would choose to use them. Other reasons why students would buy an electric vehicle are: comfort (1.1\%), reliability $(6.5 \%)$ or design $(2 \%)$.



Figure 1. Factors determining the decision to buy an electric vehicle.

Starting from the results in Figure 1, the authors aimed to determine if the gender influences the factors determining the decision to buy an electric vehicle, this being the second statistical hypothesis of the research. For this purpose, the $\chi^{2}$ test was applied and the results are presented in the table below (Table 5).

Table 5. Chi-square test values.

\begin{tabular}{lccc}
\hline & Value & df & Significance Level \\
\hline Pearson & 38.312 & 7 & 0.000 \\
Chi-Square & 462 & & \\
No. of valid cases & 462 & \\
\hline
\end{tabular}


Considering a 95\% confidence level, the significance level of the Chi-square test has the value 0 , therefore being less than 0.05 . In this case, the conclusion is that gender influences the factors determining the decision to buy an electric vehicle.

The results presented in the chart below show that females would buy an electric vehicle due to the financial aspects (consumption, urban efficiency, associated costs) in a higher proportion than the males. On the other hand, more males than females are interested in the technology enhanced in an electric vehicle, the environmental protection by using such a vehicle, or other aspects such: the vehicle modern design or its comfort.

Given that a high percentage of the interviewed students (62.2\%) do not wish to purchase an electric car, it was considered necessary to analyze the barriers that they face in making a favorable decision. Figure 2 shows that out of a total of 759 respondents who gave a negative answer, about half $(43.2 \%)$ would not buy an electric vehicle because of the very high price, compared to a conventional vehicle. One third of the respondents $(31.9 \%)$ are reluctant to buy due to the lack of an appropriate specific infrastructure that involves charging stations and their maintenance, billing systems, power generation solutions, electricity distribution and storage, space providers. The authors consider that it is extremely important for the respondents to know that the Romanian Government assumes the main role to support the development of the loading infrastructure and the market in the early stages of development, so that by 2030 this type of vehicles will be a regular presence in traffic, contributing to the reduction of exhaust gas emissions [48].



Figure 2. Gender differences on the factors determining the decision to buy an electric vehicle.

The technical characteristics and, especially, the limited autonomy of movement, is the barrier considered by $19.1 \%$ of the respondents who are not willing to purchase an electric vehicle (Figure 3 ). The main problem of the electric vehicle is the difficulty of storing electricity. From the sustainability perspective, there is also the issue of emissions related to the production of electricity, dominated by fossil fuels [48]. Only 5.8\% of the respondents do not consider the purchase of an electric vehicle for other personal reasons, related to the individual perception on this topic created by internal or external factors.

Starting from the results illustrated in Figure 2, the authors aimed at determining if the gender influences the type of barriers that appear in the decision to purchase an electric vehicle, this being the third statistical hypothesis of the research. For this purpose, the $\chi^{2}$ test was applied and the results are presented in the Table 6.

Considering a $95 \%$ confidence level, the significance level of the test has the value 0.015 , therefore being less than 0.05 . In this case, the conclusion is that the gender influences the type of barriers that appear in the decision to purchase an electric vehicle. 


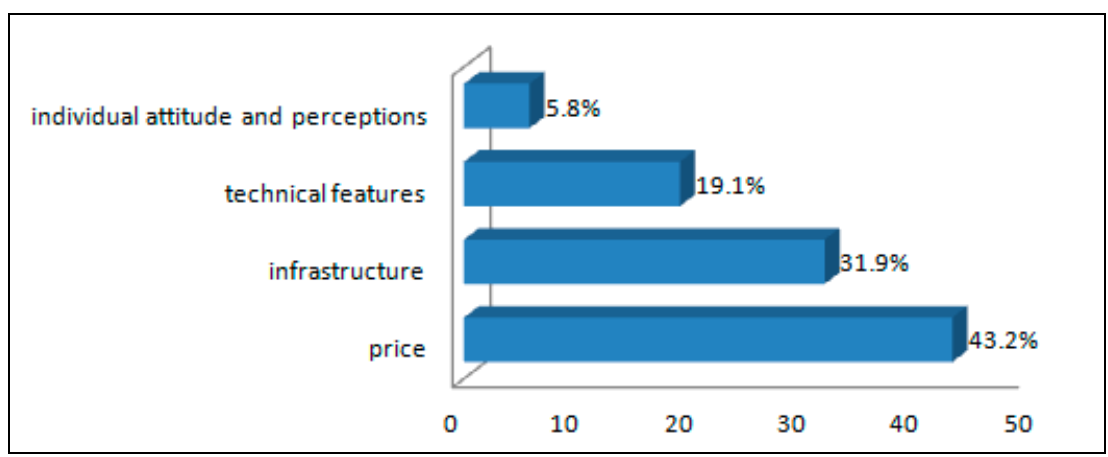

Figure 3. Barriers to the acquisition of an electric vehicle.

Table 6. Chi-square test values.

\begin{tabular}{lccc}
\hline & Value & df & Significance Level \\
\hline Pearson & 10.491 & 7 & 0.015 \\
Chi-Square & 759 & & \\
No. of valid cases & 759 & \\
\hline
\end{tabular}

The results presented in the chart below (Figure 4) show that females consider that the transportation infrastructure specific for the electric vehicles and their technical features are an important barrier for the acquisition, in a higher proportion than the males. On the other hand, more males than females are concerned about the price or they have certain perceptions that make them postponing the acquisition.

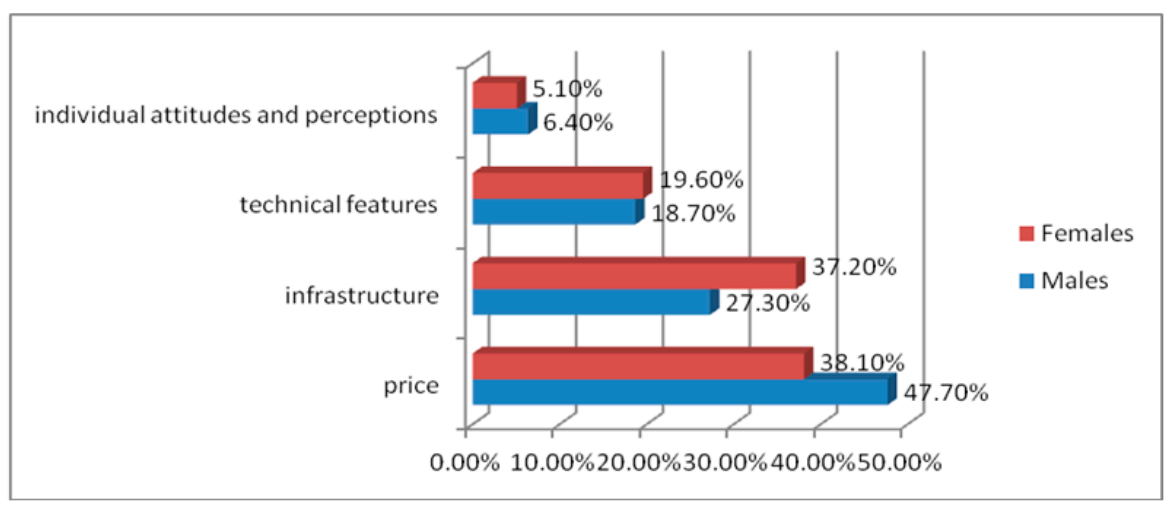

Figure 4. Gender differences on the barriers to the acquisition of an electric vehicle.

\subsection{Overview on Costs and Financial Benefits Regarding the Acquisition of an Electric Vehicle in Romania}

One of the directions for the development of the energy sector mentioned in the Energy Strategy of Romania 2016-2030 concerns electromobility, by promoting hybrid and electric vehicles, including cars, buses and light-duty vehicles dedicated to the urban environment [48].

According to the research results, if the students would receive financial support from the state, the percentage of those who intend to buy an electric vehicle reaches $81.1 \%$. Starting from these results, but also taking into account the optimal scenario of the transition to electromobility in Romania which anticipates that by 2050 about 10 million vehicles will be registered in Romania, 19\% being electric vehicles and 1.5\% with hydrogen fuel cell batteries [48], an overview on the costs and financial benefits provided by the Romanian Government to the electric vehicles owners, such as acquisition price reductions or tax reductions. The starting point was the question to which many Romanians seek an answer: Is it worth buying an electric vehicle in Romania? 
Many car importers in Romania sell also electric cars and their sale price is quite high, compared to the purchasing power of Romanians but also compared to the price of a conventional vehicle. From this point of view, the authors aimed at analyzing the costs and financial benefits for buying and using a gasoline vehicle compared to an electric one, both produced by Volkswagen. The models selected for the analysis, are: the electric model VW e-UP! (one of the best-selling models of the German manufacturer and among the cheapest electric cars in Romania) and VW UP 1.0 L petrol, with a 1000 cc engine.

The following table (Table 7) compares certain costs and financial benefits involved for both vehicle models.

Table 7. Comparison of financial aspects between electric and gasoline vehicle.

\begin{tabular}{lcc}
\hline \multicolumn{1}{c}{ Financial Aspects } & VW e-UP! & VW UP 1.0 L Gasoline \\
\hline Purchase price & 16.536 Euros * & 8.729 Euros ** \\
List price & 27.431 Euros & 10.104 Euros \\
Eco-ticket & 9.520 Euros & - \\
Scrapping premium & 1.375 Euros & 1.375 Euros \\
Consumption & 1.26 Euros $/ 100 \mathrm{~km} \approx 12 \mathrm{Kw})$ & 5 Euros/100 km $(4.2 \mathrm{~L})$ \\
Taxes & 1 year: 460 Euros & 8.50 Euros/year \\
\hline & 5 years: 2.300 Euros & 1 year: 1.825 Euros \\
Operating cost & 10 years: 4.600 Euros & 5 years: 9.125 Euros \\
& 1 year $=16.996$ Euros & 10 years: 18.250 Euros \\
\hline Total cost & 5 years $=18.836$ Euros & 1 year $=10.563$ Euros \\
(purchase + operating) & 10 years $=21.136$ Euros & 5 years $=17.897$ Euros \\
\end{tabular}

* includes the 1375 euro scrapping premium and $\approx 9520$ euro eco-ticket; ${ }^{* *}$ includes the scrapping premium of 1.375 euro.

The big advantage of the electric model is the operating cost, because it has a consumption of about $12 \mathrm{kw} / 100 \mathrm{~km}$, which means about 6 lei for every $100 \mathrm{~km}$ travelled, the price/kilowatt being around 0.50 lei. Thus, estimating that the owner travels, on average, $100 \mathrm{~km}$ daily, for 365 days, it reaches an annual operating cost of 460 Euros. During five years, the operating cost of an electric car, from which other maintenance costs are excluded, will be 2300 Euros, and in 10 years, the owner will pay 4600 Euros for the electricity consumed. As electric cars are not taxed in Romania, the conclusion is that, in terms of operating costs, the electric model analyzed is cost effective, but not necessarily from the point of view of the initial financial investment.

If the consumer would decide to buy the model VW UP 1.0 L gasoline equipped with a $1000 \mathrm{cc}$ petrol engine, he would save about 7800 Euros compared to the electric model. Considering the average consumption of $4.2 \mathrm{~L} / 100 \mathrm{~km}$, it means that a driver who travels daily on this distance, for one year, will spend 1825 Euros on fuel, and in 5 years, would spend only on gasoline. 9.125 Euros, while in 10 years, 18,250 Euros. Moreover, adding an annual tax of approximately 8.50 Euros, the total cost of buying and operating the car would be 10,563 Euros/1 year, which represents 17,897 Euros/5 years and 27,064 Euros/10 years.

For this overview on financial aspects regarding the 2 vehicle models, the authors did not consider the maintenance cost. The main reason is that in Romania, the electric vehicles market is still a young one, with a few owners who are still adapting to these products, and there are no statistics available for the maintenance cost on medium or long term. Considering this situation, it is difficult to forecast an appropriate maintenance cost for electric vehicles. However, the owners should consider that the maintenance costs for a conventional vehicle are lower compared to the electric vehicles due to the small businesses providing assistance and service. For electric vehicles, the owners can appeal only the official dealers for maintenance at expensive prices. The conclusion is that it takes more than five years to repay the investment in an electric vehicle, compared to a similar car on petrol, but only if the 
support of 45,000 lei ( $\approx 9520$ Euros) is granted by the state through the Rabla Plus program. Since the batteries that store the electricity in electric vehicles degrade over time, it requires that, after 5-10 years, they be replaced, which determines that at the final operating price of an electric car about 6000 Euros will be added. Thus, it has been found that within 10 years of use, electric cars reach costs similar to the classic cars that use fossil fuels.

An electric vehicle is not only good for the environment, as it has been shown in this paper, because it does not pollute, but it also offers advantages in terms of comfort and safety. Almost all the car manufacturers consider this to be the future, as proof is that, every year, more and more electric cars appear and there are more and more owners. However, when looking at the investment from a financial point of view, it can be seen that, on the long term, there are no big differences between an electric vehicle and one that uses fossil fuel. Basically, if only the purchase price and the fuel price are taken into account, the money saved by purchasing a conventional car will be spent on fuel. As well, conversely, the money saved by using the electricity will be spent on replacing the batteries of electric vehicles. In conclusion, potential consumers who have to decide whether it is worth buying an electric or gasoline/diesel-powered vehicle must first consider the initial purchase cost.

\section{Conclusions}

The article contributes to the literature through the novelty of the researched problem: identification and analysis of the attitude and behavior of Romanian students regarding the purchase of electric vehicles. For achieving this objective, the research was structure on 3 main themes in order to analyze: The students' knowledge regarding the green consumption (1), the students' intentions to buy electric vehicles (2) and an overview on costs and benefits regarding the acquisition of an electric vehicle in Romania (3).

The research results confirm the results of other studies from the literature $[8,9,36-38,40]$. Regarding the first research theme, the authors found out that almost half of the interviewed students $(49.5 \%)$ know nothing about green consumption. On the other hand, considering the age groups, an encouraging aspect is that, from those who have knowledge about green consumption, the youngest students (18-21) are more interested than the older ones in this issue. So, the young consumers tend to be more informed and perhaps behave more according to the green consumption principles. Another good news is that the views of young Romanians are similar to those of young people from economically advanced European countries, such as United Kingdom, proven fact by the percentage of students who would be willing to buy an electric vehicle (37.8\% of the Romanians, $40 \%$ of the British young people). The most important reason why the students would buy an electric vehicle is the fuel consumption, in terms of price and resources (mentioned especially by female students), followed by the willing to participate somehow into the protection and conservation of the environment (mentioned especially by male students).

From those students who do not consider to buy an electric vehicle, about half of them mentioned the very high price, compared to a traditional vehicle, but in the case of receiving some financial support from the Government, $81,1 \%$ would change their mind and consider buying such a vehicle. The overview on the costs and financial benefits provided by the Romanian Government to the electric vehicles owners highlighted that in terms of operating costs, the electric model analyzed is cost effective, but not necessarily from the point of view of the initial financial investment. On the long run, there are no big differences between an electric vehicle and one that uses fossil fuel. Basically, if only the purchase price and the fuel price are considered, the money saved by purchasing a conventional car will be spent on fuel. The financial effort for buying an electric vehicle is bigger than for a conventional one, but the advantages in terms of consumption costs and environmental protection are very important to consider on the long term. The general conclusion of the paper emphasizes the importance of the research results for the public institutions, the necessity of their involvement being highlighted in other papers $[11,20,23,24,26]$ as well as for the academic environment. The support Romania provides through the Rabla Plus program for the purchase of electric vehicles is a significant one, but, considering 
the purchasing power in our country, electric cars, even with this financing from the state, still fall into the category of expensive products. Also taking into account the research results, the authors recommend to the competent public institutions to elaborate special programs, by offering attractive facilities for the young people with higher education, in order to procure an electric vehicle. This way is diminished the effect of the barrier generated by the high price. From the academic environment perspective, it is necessary to initiate and develop researches, both at micro and macroeconomic level, to quantify the economic-social implications of green acquisitions in general and of electric cars in particular, as well as to include the concept of green acquisition in the curricula of some study programs to generate a high level of education in order to change the behavior of young people in the direction of environmental conservation and to achieve a competitive economy based on low carbon emissions.

The main research limit is the sample selection method, which is not performed using a random method, leading to a reduced representativeness for the researched population. However, the authors consider that the large volume of the sample and the balanced structure on academic centers are elements that mitigate the specified disadvantages.

Future research should be extended to the entire adult population in order to quantify with more scientific rigor its attitude and behavior regarding the acquisition of electric vehicles, which in turn will require the use of qualitative methods, which will capture the benefits perceived by the potential Romanian consumers. The authors also intend to carry out quantitative marketing research, representative at national level, based on random sample selection methods.

Author Contributions: Conceptualization, G.B., R.B., I.B.C.; Investigation, A.T., L.D., R.D.T. and R.B.; Methodology, G.B., L.D. and I.B.C.; Supervision, G.B.; Writing-original draft, L.D.

Funding: This article was supported by the Transilvania University of Brasov, Romania.

Conflicts of Interest: The authors declare no conflict of interest.

\section{References}

1. Parlamentul European. Reducerea Emisiilor de CO2: Obiective și Măsuri UE. Available online: https: //www.europarl.europa.eu/news/ro/headlines/priorities/schimbarile-climatice/20180305STO99003 (accessed on 3 September 2019).

2. Parlamentul European. Emisiile de CO2 de la Autovehicule: Date și Cifre. Available online: http://www.europarl.europa.eu/news/ro/headlines/society/20190313STO31218/emisiile-de-co2-dela-autovehicule-date-si-cifre-infografic (accessed on 3 September 2019).

3. Biresselioglu, M.E.; Kaplan, M.D.; Yilmaz, B.K. Electric mobility in Europe: A comprehensive review of motivators and barriers in decision making processes. Transp. Res. Part Policy Pract. 2018, 109, 1-13. [CrossRef]

4. Schneidereit, T.; Franke, T.; Günther, M.; Krems, J.F. Does range matter? Exploring perceptions of electric vehicles with and without a range extender among potential early adopters in Germany. Energy Res. Soc. Sci. 2015, 8, 198-206. [CrossRef]

5. Dabija, D.C.; Postelnicu, C.; Dinu, V. Cross-Generational investigation of ethics and sustainability. insights from romanian retailing. In Current Issues in Corporate Social Responsibility; Idowu, S.O., Sitnikov, C., Eds.; Springer International Publishing: Cham, Switzerland, 2018; pp. 141-163. [CrossRef]

6. Biresselioglu, M.E.; Nilsen, M.; Demir, M.H.; Røyrvik, J.; Koksvik, G. Examining the barriers and motivators affecting European decision-makers in the development of smart and green energy technologies. J. Clean. Prod. 2018, 198, 417-429. [CrossRef]

7. Carlucci, F.; Cirà, A.; Lanza, G. Hybrid Electric Vehicles: Some Theoretical Considerations on Consumption Behaviour. Sustainability 2018, 10, 1302. [CrossRef]

8. Seixas, J.; Simões, S.; Dias, L.; Kanudia, A.; Fortes, P.; Gargiulo, M. Assessing the cost-effectiveness of electric vehicles in European countries using integrated modeling. Energy Policy 2015, 80, 165-176. [CrossRef]

9. Morton, C.; Anable, J.; Nelson, J.D. Exploring consumer preferences towards electric vehicles: The influence of consumer innovativeness. Res. Transp. Bus. Manag. 2016, 18, 18-28. [CrossRef] 
10. Vassileva, I.; Campillo, J. Adoption barriers for electric vehicles: Experiences from early adopters in Sweden. Energy 2017, 120, 632-641. [CrossRef]

11. Nilsson, M.; Nykvist, B. Governing the electric vehicle transition-Near term interventions to support a green energy economy. Appl. Energy 2016, 179, 1360-1371. [CrossRef]

12. Popescu, D. Marea Britanie urmează exemplul Franței: Regatul Unit vrea să interzică vânzarea mașinilor diesel și pe benzină în 2040, Automarket 2017. Available online: http://www.automarket.ro/stiri/mareabritanie-urmeaza-exemplul-frantei-regatul-unit-vrea-sa-interzica-78675.html (accessed on 15 August 2019).

13. Mester, M. Propunere de lege în Olanda: Fără mașini diesel și pe benzină începând cu 2025, Automarket 2017. Available online: http://www.automarket.ro/stiri/propunere-de-lege-in-olanda-fara-masini-diesel-sipe-benzina-incepand-cu-72805.html (accessed on 15 August 2019).

14. Popescu, D. Franța vrea să interzică vânzarea mașinilor diesel și pe benzină în 2040, Automarket 2017. Available online: http://www.automarket.ro/stiri/franta-vrea-sa-interzica-vanzarea-de-masini-diesel-si-pebenzina-pana-in-78295.html (accessed on 15 August 2019).

15. Barza, V. Miracol norvegian? Cum a ajuns țara scandinavă prima din lume unde mașinile electrice au peste jumătate din piața mașinilor noi, HotNews 2019. Available online: https://economie.hotnews.ro/stiri-auto-23064248-miracol-norvegian-cum-ajuns-tara-scandinavaprima-din-lume-unde-masinile-electrice-peste-jumatate-din-piata-masinilor-noi.htm (accessed on 7 November 2019).

16. Norwegian Ministry of Transport and Communications. National Transport Plan 2018-2029. 2018. Available online: https://www.regjeringen.no/contentassets/7c52fd2938ca42209e4286fe86bb28bd/en-gb/pdfs/ stm201620170033000engpdfs.pdf (accessed on 8 November 2019).

17. Dale, J.G.; Minister of Transport. Norway and Electric Vehicles-A Successful Combination. 2019. Available online: https://www.regjeringen.no/en/aktuelt/norway-and-electric-vehicles--a-successful-combination/ id2644216/ (accessed on 8 November 2019).

18. Norsk Erbilforening. Norwegian EV Policy. 2019. Available online: https://elbil.no/english/norwegian-evpolicy/ (accessed on 8 November 2019).

19. Nissan. Ce beneficii legale ai când conduci un autovehicul electric? Available online: https://www.nissan. ro/blog-vehicule-electrice/legislatie/beneficii-legale-cand-conduci-un-vehicul-electric.html (accessed on 15 August 2019).

20. Silvia, C.; Krause, R.M. Assessing the impact of policy interventions on the adoption of plug-in electric vehicles: An agent-based model. Energy Policy 2016, 96, 105-118. [CrossRef]

21. Xu, S.; Chu, C.; Ju, M.; Shao, C. System Establishment and Method Application for Quantitatively Evaluating the Green Degree of the Products in Green Public Acquisition. Sustainability 2016, 8, 941. [CrossRef]

22. Pacheco-Blanco, B.; Bastante Ceca, M.J. Green public acquisition as an initiative for sustainable consumption. An exploratory study of Spanish public universities. J. Clean. Prod. 2016, 133, 648-656. [CrossRef]

23. Palm, J.; Backman, F. Public acquisition of electric vehicles as a way to support a market: Examples from Sweden. Int. J. Electr. Hybrid Veh. 2017, 9, 253-268. [CrossRef]

24. Testa, F.; Annunziata, E.; Iraldo, F.; Frey, M. Drawbacks and opportunities of green public acquisition: An effective tool for sustainable production. J. Clean. Prod. 2016, 12, 1893-1900. [CrossRef]

25. Mosgaard, M.A. Improving the practices of green acquisition of minor items. J. Clean. Prod. 2015, 90, $264-274$. [CrossRef]

26. da Silva, M.B.; Moura, F. Electric vehicle diffusion in the Portuguese automobile market. Int. J. Sustain. Transp. 2016, 10, 49-64. [CrossRef]

27. Niculescu, M.; Românii s-au orientat către mașinile ecologice. Românii s-au orientat către mașinile ecologice. Câte autoturisme hibride și electrice s-au vândut până acum. Libertatea. Available online: https://www.libertatea.ro/stiri/romanii-s-au-orientat-catre-masinile-ecologice-cate-autoturismehibride-si-electrice-s-au-vandut-pana-acum-2681624 (accessed on 15 August 2019).

28. Rezvani, Z.; Jansson, J.; Bodin, J. Advances in consumer electric vehicle adoption research: A review and research agenda. Transp. Res. Part. Transp. Environ. 2015, 34, 122-136. [CrossRef]

29. Westin, K.; Jansson, J.; Nordlund, A. The importance of socio-demographic characteristics, geographic setting, and attitudes for adoption of electric vehicles in Sweden. Travel Behav. Soc. 2018, 13, 118-127. [CrossRef] 
30. Shao, J.; Taisch, M.; Ortega-Mier, M. A grey-DEcision-MAking Trial and Evaluation Laboratory (DEMATEL) analysis on the barriers between environmentally friendly products and consumers: practitioners' viewpoints on the European automobile industry. J. Clean. Prod. 2016, 112, 3185-3194. [CrossRef]

31. Green Car Congress. Tsinghua Review of Solid-State Li-metal Batteries Finds Great Promise, but Much Work still to be Done. Available online: https://www.greencarcongress.com/2019/01/20190103-sslmb.html (accessed on 10 August 2019).

32. Franke, T.; Neumann, I.; Bühler, F.; Cocron, P.; Krems, J.F. Experiencing range in an electric vehicle-Understanding psychological barriers. Appl. Psychol. Int. Rev. 2012, 61, 368-391. [CrossRef]

33. Rezvani, Z.; Jansson, J.; Bengtsson, M. Cause I'll Feel Good! An Investigation into the Effects of Anticipated Emotions and Personal Moral Norms on Consumer Pro-Environmental Behavior. J. Promot. Manag. 2017, 23, 163-183. [CrossRef]

34. Li, W.; Long, R.; Chen, H.; Geng, J. A review of factors influencing consumer intentions to adopt battery electric vehicles. Renew. Sustain. Energy Rev. 2017, 78, 318-328. [CrossRef]

35. Degirmenci, K.; Breitner, M.H. Consumer purchase intentions for electric vehicles: Is green more important than price and range? Transp. Res. Part Transp. Environ. 2017, 51, 250-260. [CrossRef]

36. Morton, C.; Anable, J.; Nelson, J.D. Consumer structure in the emerging market for electric vehicles: Identifying market segments using cluster analysis. Int. J. Sustain. Transp. 2017, 11, 443-459. [CrossRef]

37. Rezvani, Z.; Jansson, J.; Bengtsson, M. Consumer motivations for sustainable consumption: The interaction of gain, normative and hedonic motivations on electric vehicle adoption. Bus. Strategy Environ. 2018, 27, 1272-1283. [CrossRef]

38. He, X.; Zhan, W.; Hu, Y. Consumer purchase intention of electric vehicles in China: The roles of perception and personality. J. Clean. Prod. 2018, 204, 1060-1069. [CrossRef]

39. Wu, J.; Liao, H.; Wang, J.W.; Chen, T. The role of environmental concern in the public acceptance of autonomous electric vehicles: A survey from China. Transp. Res. Part Traffic Psychol. Behav. 2019, 60, 37-46. [CrossRef]

40. Han, L.; Wang, S.; Zhao, D.; Li, J. The intention to adopt electric vehicles: Driven by functional and non-functional values. Transp. Res. Part Policy Pract. 2017, 103, 185-197. [CrossRef]

41. Barbarossa, C.; De Pelsmacker, P.; Moons, I. Personal Values, Green Self-identity and Electric Car Adoption. Ecol. Econ. 2017, 140, 190-200. [CrossRef]

42. Barbarossa, C.; Beckmann, S.C.; De Pelsmacker, P.; Moons, I.; Gwozdz, W. A self-identity based model of electric car adoption intention: A cross-cultural comparative study. J. Environ. Psychol. 2015, 42, 149-160. [CrossRef]

43. Wang, S.; Fan, J.; Zhao, D.; Yang, S.; Fu, Y. Predicting consumers' intention to adopt hybrid electric vehicles: Using an extended version of the theory of planned behavior model. Transportation 2016, 43, 123. [CrossRef]

44. Peters, A.M.; van der Werff, E.; Steg, L. Beyond purchasing: Electric vehicle adoption motivation and consistent sustainable energy behaviour in The Netherlands. Energy Res. Soc. Sci. 2018, 39, $234-247$. [CrossRef]

45. Barbu, A.; Isaic-Maniu, A. Data collection in Romanian market research: A comparison between prices of PAPI, CATI and CAWI. Manag. Mark. Chall. Knowl. Soc. 2011, 6, 349-364.

46. Dinu, V.; Săvoiu, G.; Dabija, D.C. A concepe, a redacta şi a publica un articol stiintific. O abordare în contextul cercetării economice; Editura ASE: București, Romania, 2016.

47. Hobbs, A. Half of 25-34 Year-Olds Want to Own an Electric Vehicle. Available online: https://internetofbusiness.com/half-of-25-34-year-olds-want-to-own-an-electric-vehicle/ (accessed on 15 August 2019).

48. Ministerul Energiei. Strategia Energetică a României 2016-2030, cu perspectiva anului 2050. Available online: http://www.mmediu.gov.ro/app/webroot/uploads/files/2017-03-02_Strategia-Energetica-a-Romaniei2016-2030.pdf (accessed on 12 August 2019).

(C) 2019 by the authors. Licensee MDPI, Basel, Switzerland. This article is an open access article distributed under the terms and conditions of the Creative Commons Attribution (CC BY) license (http://creativecommons.org/licenses/by/4.0/). 